\title{
教育博物館の平面計画について \\ A STUDY ON ABOUT THE FLOOR PLANNING OF THE EDUCATIONAL MUSEUM
}

河田健*

Takeshi KAWATA

The educational museum included the office and the library in time of opening of 1877 . The plan in 1881 is an exhibition room the entire building, and seems a finished type.

The plan of The Kyoto museum exists as a museum project plan planned to a simultaneous period, The educational museum and The Kyoto museum are the flow plannings based on the same idea. It is thought that The plan of The Kyoto museum is transmitted from Makimura to Tanaka through Kido is high, and The educational museum was planned based on The plan of The Kyoto museum.

Keywords : The educational museum, exhibition movement line, plan of The Kyoto museum,

Fujimaro Tanaka, Takayoshi kido, Masanao Makimura

教育博物館，展示動線，京都博物館案，田中不二麿，木戸孝允，槙村正直，

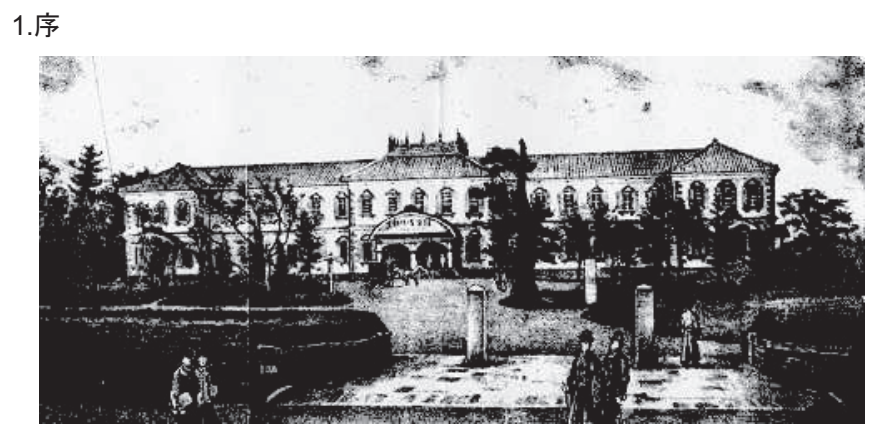

写真 1 教育博物館

明治初期、博覧会や学校教育の導入とともに、わが国に博物館が導 入された。当初は昌平坂学問所や薩摩藩装束屋敷など既存の日本建 築を利用したもので対応していたケースが多く見受けられるが ${ }^{11}$ 、 明治 10 年には洋風建築による教育博物館が開館している。この教育 博物館は、わが国で博物館として建設された初期の博物館建築であ り、その平面計画は順路動線を採用するなど博物館独特の特徵を有 している。

教育博物館の平面は、明治 14 年の「教育博物館案内」に載せられ たものが知られている。2)この平面図は「国立科学博物館百年史」 (以下「百年史」と記す。) や「写真で見た国立科学博物館 120 年の 歩み」、その他椎名仙卓の著書など博物館史の文献に当時の状沉を知
る資料として取り上げられている。 ${ }^{3)}$ 教育博物館の開館は明治 10 年 8 月であり、明治 14 年の平面図は開館当初と若干変わっている可 能性が考えられるが、開館当初の平面は近代建築および博物館史の 分野では明らかにされていない。その他教育博物館は順路動線を可 能とする平面計画となっており、この特徵はほぼ同時期に計画され たと考えられる京都博物館案 ${ }^{4)}$ と共通点を確認寸ることができるが、 当時の博物館計画の関係について考察された研究は見いだせない。

そこで本稿は、教育博物館の平面計画について考察を行い、開館 当初の平面計画を検証すると共に、類似した特徵を持つ計画案であ る京都博物館案との関係について考察するものである。教育博物館 の平面計画について検証することは、わが国の黎明期の博物館の施 設整備過程を知るうえで重要なことであると考えている。

なお文部省の博物館は、明治 4 年に設立されるが博物館事務局に 合併され一時閉鎖、分離後の明治 8 年 5 月に東京博物館と改称、更 に明治 10 年 1 月には教育博物館と改称され期間によって名称が変わ っていくが、本稿では当該施設開館当初の教育博物館の名称で統一 するものとする。

\section{2 .教育博物館の計画された経緯について}

明治初期の博物館は、お雇い外国人が計画しているものが多いな か、教育博物館の計画・設計は日本人が行ったとされているが、具

\footnotetext{
* 佐藤総合計画 主任担当

Architect, Design Chief, AXS SATOW INC.
} 
体的な設計者および建築計画・設計期間は特定されていない。堀越 三郎によると教育博物館は「本邦建築家設計の官庁建築」5) と整理 されている程度であり、その他「百年史」の中では「博物館の新築 は学校に属するものとして、文部省の手で造営されることになり」

6) と記述されている。教育博物館の計画された経緯について整理す ると以下のようになる。

文部省の博物館は、明治 4 年にわが国最初の博物館として設立さ れたが、明治 6 年 3 月太政官正院におかれた博覧会事務局に合併さ れた。文部省は博物館の設置目的の違いを主張し、博覧会事務局か らの分離する動きを行うことになる。教育博物館が単独分離するま で文部大輔田中不二麿と町田久成が対立したことが知られている。

7) 田中不二麿は、尾張藩出身で明治 4 年より文部大丞となり岩倉使 節団に加わっており、明治 7 年より文部大輔となる人物である。 ${ }^{8)}$

合併から 2 力月後の明治 6 年 5 月 8 日、 2 週間後の 5 月 30 日に田 中不二麿は、文部省の博物館と太政官正院の博覧会事務局との分離 の上申を正院に提出している。正院から回答が無いため、田中不二 麿は 7 月 15 日に太政大臣三条実美に、11月 10 日には右大臣岩倉具 視に、更に翌年明治 7 年 1 月 13 日再度三条実美に上申書を提出して いる。そして 2 月 14 日には文部卿就任早々の木戸孝允から三条実美 に上申書を提出している。9)

明治 8 年 2 月 9 日文部省の博物館の分離は、太政大臣三条実美よ り認められると、明治 8 年 3 月 13 日博物館・書籍館両館が同居並存 として湯島の昌平館に事務局を設置した。館長は博物館書籍館を兼 務して畠山義成が就任した。博物館側の職員は、御用掛として永井 久一郎、山科元行、有田速。10) 畠山義成は、薩摩藩出身で元治 2 年 の薩摩藩英国留学生 15 名のなかの一人である。慶応 4 年よりアメリ カのラドガースカレッジで学び、明治 4 年の岩倉使節団に随行し久 米邦武と共に書記官を務めている。その後明治 6 年 12 月東京開成学 校長兼外国語学校長となっていた。 ${ }^{11)}$ その他文部省にはラドガース カレッジで教鞭をとっていたお雇い外国人ディビット・マレーが在 籍していた。

ディビット・マレーについては、教育博物館の設立に大きな影響 を与えた人物として、博物館史の分野でいくつか取り上げられてお り、資料収集を中心に彼の働きが明らかにされているが、施設整備 に関係している記述は見いだせない。

政府は明治 9 年のフィラデルフィアで開かれる独立百年記念万国 博覧会への参加を決め、明治 8 年 1 月には米国博覧会事務局を設置 し準備にとりかかっている。吉家定夫によると、ディビット・マレ 一の妻マーサから従姉妹のルーシーに宛てた書簡より、文部省は 6 月にはディビット・マレーをアメリカに派遣するよう打診していた ことが確認されている。10月７日には正式に契約を交わしており、 この時の契約内容が明らかにされている。ディビット・マレーとの 契約内容は、「1)フィラデルフィア万国博覽会での各国の教育展示を 視察調查のうえ報告書を作成すること。(2)東京に設立を予定されて いる学術博物館に展示するさまざまな教育関連物件（教育関係書、 学校の器具備品、校則、校舎の模型など）を収集購入すること。(3) 望遠鏡の購入の三つである。」と記述されている。12)ここに示され ている「東京に設立を予定されている学術博物館」が教育博物館の ことである。ここでもディビット・マレーに対して施設整備に関す る調查業務等は含まれていない。そしてディビット・マレーは 10
月 11 日より横浜からアメリカに向け出発することになる。

明治 9 年 3 月 22 日田中不二麿は太政大臣三条実美に上野に博物館 を建設する上申を提出した。この上申の文書の中で田中不二麿は、

「上野山内當省用地二於テ先以學術博物場,一部 次増築逐二該館ノ完全ニ至ルヨ要ス尤該費用八金壱万五千圓以内ノ 見込ニテ當会計年度當省額外常費營繥費ノ範囲二在テ可相辦候條速 二充裁相成候様致度此旨相伺候也」 ${ }^{13)}$ と記述している。つまり取り 急ぎ施設の一部を整備し、順次増築しながら施設を整備することを 想定しているというものである。そして最初の施設整備にかかる概 算費用 15,000 円を算出している。

上申後まもなく教育博物館は、3 月 29 日博物館の事務局は湯島か ら上野山内の東四軒寺町跡（現在の国立科学博物館あたり）の東京 医学校教師館の第一舎に仮移転している。

ディビット・マレーにつづきフィラデルフィアの独立百年記念万 国博覧会には、田中不二麿、畠山義成、阿部泰蔵、手島精一、出浦 力雄の 5 名が訪れている。彼らは明治 9 年 4 月から明治 9 年 12 月ま でアメリカに出張しており国内にいなかった。14)

教育博物館の建築計画は責任者である田中不二麿・畠山義成不在 の中進んでいったとは考え難く、彼らの渡米以前に行われていた可 能性が高いと思われる。予算や工期を把握する上でも田中不二麿が 博物館建設を上申した明治 9 年 3 月 22 日の段階では既に計画案が出 来上がっていた可能性が高いと考えられる。田中不二麿に代わって 業務を行っていたのは九鬼隆一である。九鬼隆一は、畠山義成の病 気療養中から館長事務取扱を行っていた。 ${ }^{15)}$ 田中不二麿・畠山義成 不在時に、九鬼隆一は農商務省の博物館との敷地問題等に関して調 整業務を行っていたことが確認されているが、16) 建築計画との関わ りについては今のところ文書等確認できていない。教育博物館の建 築計画は、やはり渡米前にほとんどのことが決まっていたと考える のが妥当であろう。

以上のことから教育博物館は、単独分離した明治 8 年 2 月以降、 田中不二麿・畠山義成が渡米する前の明治 9 年 3 月まで約 1 年の間 に建築計画が行われていたものと設定できる。

教育博物館の新築工事は会計年度内での予算執行の関係から 6 月 中旬に着工した。新館は 12 月には一部を残してほぼ出来上がってい たとされており、明治 10 年 3 月 9 日に落成、 8 月 18 日開会式を行 っている。17)

\section{3 .開館時の教育博物館の平面計画について}

先にも述べたように教育博物館は、施設の一部を整備し、順次増 築しながら施設を整備することを想定しているというものであった。 つまり明治 10 年の開館当初の平面計画は、施設整備の第一段階であ ったといえる。

明治 14 年の「教育博物館案内」に示された平面図では、形状は左 右対称の直線状の平面形をしており、中央エントランスの左右に位 置する長方形の展示室の短辺方向を壁で仕切り細長い部屋割りとし、 端部の部屋に繋がっている。こうすることによって1階中央から入 り 1 階をす心゙て観覧した後、2 階を観覽し再び 1 階に戻る一筆書き のように順路通り廻れる特長のある動線計画を採用していた。

展示室は、明治 14 年の平面図では 13 室に分かれて配置されてい る。この 13 室とは、部屋数のことではなく、展示区分を示している。 
1 階エントランス正面に体育用具の小部屋があり、そこから右回り に、第一室 家庭玩具 ・ 幼稚園恩物 - 鉱物教授用具、第二室 教学 用具 - 学校模型並二撮影 - 小学物理器械、第三室 物理器械、第四 室 書画学用具 - 化学器械 - 地学及星学器械、第五室 盲壟者及痴 子教育用具 ・ 商業教育用具 $\cdot$ 卒業免除並二賞牌 教育用具、第六室 学校用椅子卓子類 - 比較解剖商品、第七室 生徒制作品並二試業答 書画類。

2 階に上がり左回りに、第八室 内国鉱物類 ・ 外国鉱物類 ・地質学 用具 - 古生物模造類、第九室 植物類、第十室 哺乳動物類、第十

一室 鳥類、第十二室 爬虫類、第十三室 魚介類となっていた。

室名の記入の無い部屋が、1 階エントランス部分と 2 階中央階段 横部分にある。1 階エントランス部分は守衛室、2 階中央階段横部 分は何らかのバックヤードであったと考えられる。

明治 10 年開館当初の教育博物館の平面計画を知る手がかりとし て、文部省年報（以下「年報」と記す。）がある。この「年報」には 当時の教育博物館の活動が記されている。

明治 10 年の「年報」には、施設整備に関して次のように記されて いる。

「三九日文部省上野公園地内新設ノ廈屋及七地所 $コ$ 本館二交付又 此地八公園ノ西北隅二位シ地坪一萬六千七百四十九坪余アリ廈屋八 敷地内ノ南部ニアリ其建坪二百十九坪余ナリ之レ素寺院ノ廃趾ニシ テ太ク荒囬ニ属スルヨ以テ更二文部省ノ禀准ヨ経テ園庭ノ樹木ヨ移

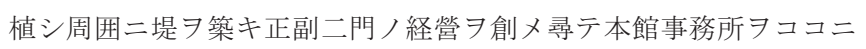
移シ車坂上ノ仮館ヨ大學醫學部二還付ス是二於テ會テ蒐集セシ物品 ヨ悉ク新館ニ移シ之ヨ類別シテ陳列場十四室二列序ス其後又物品ノ 増加セルニ隨ヒ陳列室 7 分合或八廃置シテ十八室トス」 ${ }^{18)}$

これによると本館の規模は、延床面積 219 坪（約 $724 \mathrm{~m}^{2}$ ）あった。 明治 14 年の平面図にはスケールの記載が無く、部屋の実際の寸法を 知る資料は確認できていない。そのため延床面積 $724 \mathrm{~m}^{2}$ から逆算す
ると、全体では正面側間口方向約 $50 \mathrm{~m}$ 、奥行き約 $10.5 \mathrm{~m}$ 程度の規模 であったことが考えられる。中央部のホールは $10.5 \mathrm{~m} \times 10.5 \mathrm{~m}$ 、ホ ールに隣接する部屋は $13 \mathrm{~m} \times 5.5 \mathrm{~m}$ を 2 等分し細長い部屋となって おり、端部は $8 \mathrm{~m} \times 6.5 \mathrm{~m}$ 程度、そして 1 階ポーチ部分は $2 \mathrm{~m} \times 5 \mathrm{~m}$ 程 度の規模であったと設定できる。19)

工事は明治 10 年 3 月 9 日にはほぼ竣工しており、事務所を移転し ている。本館以外に付属棟は建設されていないので、事務室は当初 本館内に配置されていたことを示している。職員は、館長 1 人、館 長補 1 人、書記 3 人、画工 1 人、物品掛 6 人、同附属 4 人、看守 3 人の計 19 人で、看守を除く 16 人が事務室で執務していたと考えら れるが、事務室がどこに位置していたかは示されていない。

展示室については 3 月から開館する 8 月までの間に展示室は当初 の 14 室から 18 室に整理し直されたことが記載されている。しかし 竣工直後に増築および間仕切り改修等を行ったとする記述がないこ とから、ここで記されている 18 室についても部屋数ではなく、展示 区分を示しているものと思われる。「百年史」には「当初の 14 室か ら後に 18 室に拡大したことがわかる。」 ${ }^{20)}$ と記述されているが，こ れは拡大ではなく、展示区分の再編であったといえる。

開館当初の教育博物館には本館内に書籍室があったことも記され ており、明治 10 年の「年報」の「教育博物館書籍館規則」には次の ような記載がある。

「第三條書籍ヨ求覧スル者八書名及七自己ノ姓名居所ヨ明記シ之ヨ 掛リ吏員ニ出シテ書籍ヨ受収スヘシ但求覧ノ書籍八室内ニ於テ謄寫 スルモ妨ケナシトス」 ${ }^{21)}$

書籍室の利用者は、書名と氏名、住所を書類に記入したものを提 出のうえ書籍を受け取り室内で閲覧する。つまり書籍室は閉架書庫 と閲覧室で構成されていた。明治 10 年段階での蔵書量は、12, 326 冊 ${ }^{22)}$ であった。書籍室のスペースに関する資料は残されていない ため仮に想定すると、これを書架配置すると書庫部分のみで約 $60 \mathrm{~m}^{2}$

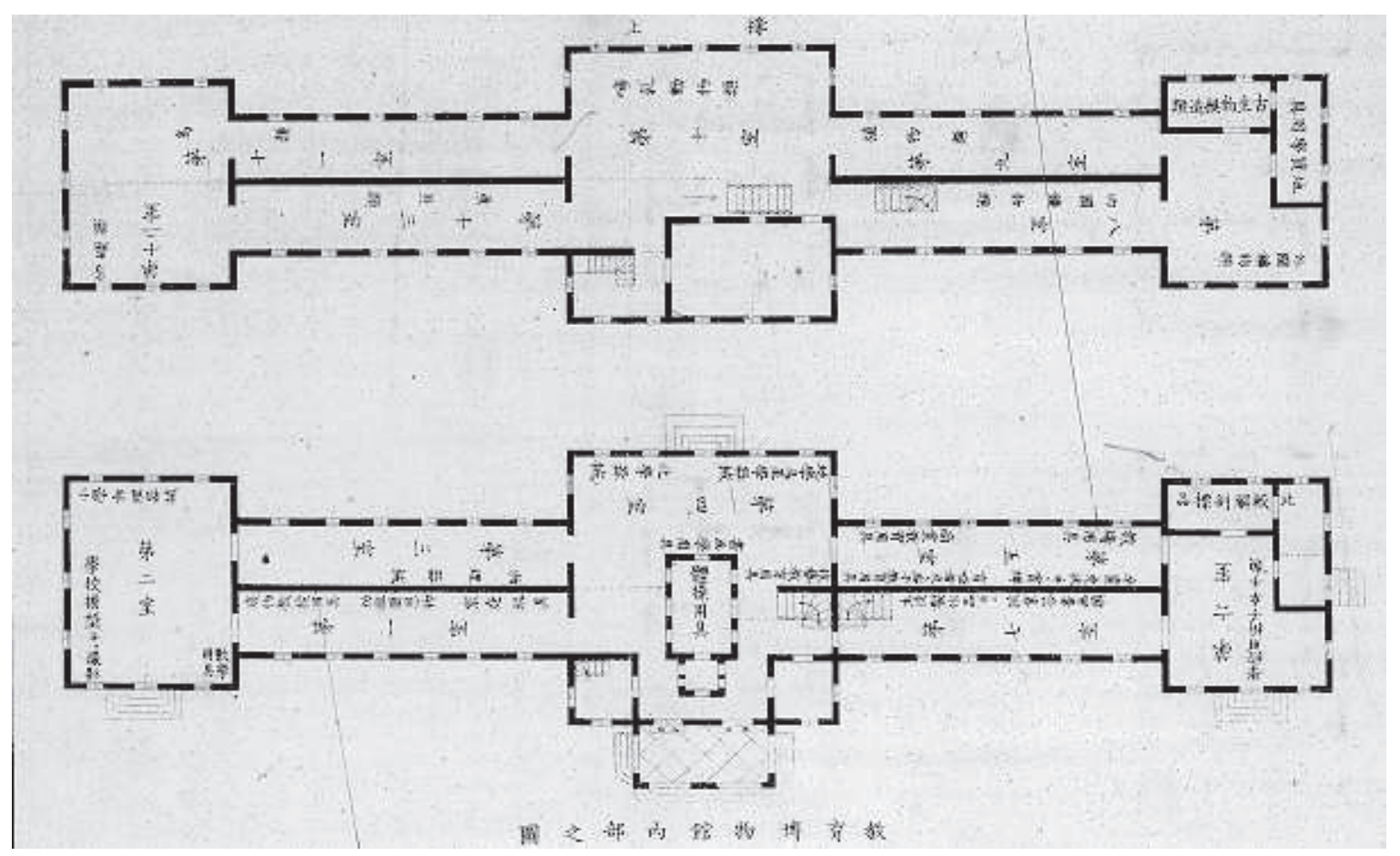

写真 2 明治 14 年教育博物館の平面図 
程度は必要だった ${ }^{23)}$ と思われる。閲覧席数を 10 席と想定すると、 受付スペースも含めて書籍室は $120 \mathrm{~m}^{2}$ 程度必要と想定できる。 お明治 10 年の情報のみでは書籍室の位置は明確になっていない。

明治 12 年の「年報」には、増築に関する記述が見受けられる。

「當館事務所甚狭监ニシテ往々事務涉滞スルヨ以テ更ニ一宇习増 築センコト

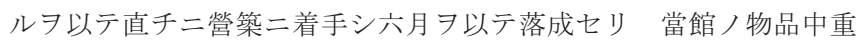
複ニ係ルモノ开二陳列前一時貯藏ノ場所ナキヨ以テ八月中文部省ノ 裁可 7 徑テ物品貯藏所一宇 $コ$ 建築ス 十二月五日文部省ノ裁可 7 徑 テ當館周圍ノ土手 7 増築ス是レ當館用地ノ中會テ東京府へ貸與セシ 中若干坪ヨ返却セショ以テナリ 同十二日文部省會テ當館ヨリ申禀 シタル書庫开圖書閲覧室各一宇ヨ建築スルコトヨ裁可ス依テ其營築 ヨ工部省二委啒ス其起工ノ日八來年ニアルヘシ」 ${ }^{25)}$

これによると事務室は 6 月に増築。8月にはそれまで無かった収 蔵庫を増築。12 月 5 日東京府より敷地の返却を受けて外構の再整備 を決定。12月 12 日に書庫及び書籍閲覧室をそれぞれ増築すること を決め工部省に委嘱している。これまで本館にあった事務室、書籍 室が別棟に移設されることで、本館内は展示室のみになり、明治 14 年の平面図に近い形が整っていった。

その他明治 12 年には展示室の配置順序を変更している。この展示 替えについては「百年史」にも記述があり、2 階部分が金石一植物

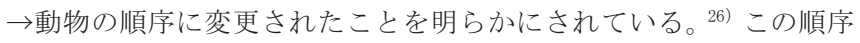
は明治 14 年の平面図にも一致している。その他明治 12 年の「年報」 には、「地質学標品古生化石物品八之习別室二排置ス」 27) と記述が あり、「古生物模造類」と若干内容が異なっているものの、明治 14 年の平面図に示された 2 階端部の小部屋がこの時点で間仕切られて いたことが確認できる。

本館の展示については、1 階に学校建築の模型、椅子卓子、理化 学機器等学校で使用する資料を展示し、2 階に植物、動物、金石な どの博物標本を展示していた。12 年の「年報」では展示替えについ て以下のような記述がある。

「階下教育陳列ノ順序モ或八兒童發育ノ順序二適セサル所ナシトセ ス然レモ館内餘地ニ乏シキヨ以テ之カ順序ヨ正クスルヨ得ス他日圖 書室新築落成シ書籍ヨ此ニ移スノ後當サニ之ヨ改正スヘキナリ」 ${ }^{28)}$

1 階の教育展示についても展示替えが必要であったがスペースが 無いため、書籍室移転の後展示替えを行うというものである。この 記述より、書籍室は当初 1 階部分に配置されていたことが確認でき る。その他明治 12 年 7 月には「教育博物館書籍室規則」も改正され ており，次のように記されている。

「第一條 本室開閉ノ時限八本館卜別ナシト雖毎年夏秋ノ際凡二 週日 $コ$ 以テ曝書ノ期限卜ス此ノ期間中八閉室ス」 ${ }^{299}$

基本的に展示を行っている部分と開館時間は同じであるが、夏秋 2 週間閉室しているというものである。つまり書籍室は閉室してい ても展示動線が変わらない位置に配置してあったものということが できる。明治 14 年の平面図でみると、1 階部分正面左側の部分に書 籍室が配置されていた可能性が高いと考えられる。この位置は、階 段が無く展示動線に影響しない位置であり、また端部の出入口より 単独の出入りも可能となる位置である。またこの範囲は蔵書量から 想定した規模にも近く、端部と隣接する部屋で約 $120 \mathrm{~m}^{2}$ となる。

スペースの問題により 1 階部分でできなかった展示替えが、2 階
部分で可能だったということは、明治 12 年の段階で 2 階部分にスペ 一スが確保できたということになる。明治 12 年 6 月には別棟の事務 所が竣工し移転していたため、事務室は本館から移転して、スペー スが確保できていた。つまり事務室は本館 2 階に配置されていたこ とになる。事務室の位置についても、展示動線に影響の無い位置で あったと考えると、2 階部分正面左側の位置が考えられる。つまり 書籍室の上階に事務室が配置されていたと推察できる。事務室も同 様に約 $120 \mathrm{~m}^{2}$ であったとすると、明治 10 年に事務室で執務していた 人数が 16 人であったことから、一人当たりのスペースは平均すると $7.5 \mathrm{~m}^{2} /$ 人となる。 ${ }^{30)}$ 若干広く感じられるが、いわゆるオフィスワ ークだけではなく画工、物品掛など作業スペースを含んでいたとす ると、この程度のスペースが確保されていたと考えることができる。

明治 13 年の「年報」には 1 階部分の展示室の変更について記載が ある。 ${ }^{31)}$ 明治 13 年 10 月 2 日に書庫及び書籍閲覧室が完成し、 1 階 部分の展示替えが行われた。これによって本館は明治 14 年の平面図 に示された状態に整えられた。

「年報」以外に開館当初の教育博物館の状況を知る資料として、 大森貝塚の発見で名高いモースによる「日本その日その日」32) があ る。開館後の明治 10 年 9 月 11 日にモースは他の外国人教授たちと 共に教育博物館に招かれている。内容を順に確認していくと「博物 館は大きな立派な二階建てで、翼があり、階下の広間の一つは大き な図書室になっている。」記述している。先にも考察した通り書籍 室が 1 階に配置されていたことが確認できる。その他「細長くて広 い部屋は、欧州及び米国から持ってきた教具に関する器具一現代式 学校建築の雛形、机、絵、地図、模型、地球儀、石盤、黒板、イン ク入れ、その他の海外の学校で使用する道具の最もこまかい物一の 広範で興味ある蒐集で満ちた。と記述している。学校教具を展示し ていることから、これは 1 階部分を説明した文章であり、明治 14 年の平面図に示すように、中央エントランス横の長方形の展示室を 短辺方向を仕切っている壁は建設当初から仕切られ、細長い部屋が 存在していたことが確認できる。

そして「階には天産物の博物館があったが、これは魚を除くと、 概して貧弱であった。と感想を述べている。 $\left.{ }^{33}\right) 2$ 階部分が植物、 動物、金石などの博物標本を展示していたことと一致している。

そして「この接待宴には、教員数名の夫人達を勘定に入れて、お 客様が百人近くいた。いろいろな広間を廻って歩いた後、大きな部 屋へ導かれると、そこにはピラミッド型のアイスクリーム、菓子、 サンドウィッチ果実その他の食品のご馳走があり、(以下省略)」と 記述しており、展示室を一通り見た後、昼食をとったようである。 食事のサービスの仕方について、「日本人が貴婦人と一緒に坐ってい る所へお血を持っていって、(以下省略)」と記述していることから、 立食ではなく着席での昼食だったことが伺える。この昼食をとった 場所について、 1 階 2 階と展示室を廻ってからこの「大きな部屋」 に導かれていること、1 階部分は、書籍室と教育展示があることを 考慮すると、2 階部分で昼食会が開かれたはずである。そして 2 階 部分では博物標本の展示室を通っていることから、先に述べた事務 室部分をホールに転用して昼食会を開いた可能性が考えられる。こ こで 100 人が着席して食事をするとホール部分のみで約 $150 \mathrm{~m}^{2}$ 程度 のスペースが必要 ${ }^{34)}$ である。サービススペースを確保すると、も う少し広いスペースを確保する必要が想定できる。実際には 100 人 
はいなかったと思われるが、2 階部分の中央ホールと左側全体を使 用したとして $200 \mathrm{~m}^{2}$ 程度確保できることから、この部分を使用して 昼食会を行ったものと想定できる。このことから開館当初は正面左 側の室には短辺方向を仕切っている壁は無く、細長い部屋は存在し なかったのである。

以上のような考察から、教育博物館施設整備の第一段階ともいえ る開館当初は、事務室、書籍室が本館内にあり、収蔵庫の無い状態 で開館していた。事務室は 2 階、書籍室は 1 階に位置しており、そ れぞれ正面向かって左側に位置しており、開館当初から順路動線は 採用されていた。

\section{4. 京都博物館案との関係}

教育博物館が計画されていた頃、同様な順路動線で計画された平 面図が京都で計画されている。オランダ人お雇い外国人のヘールツ の作成した京都博物館案は、中央にホールがあり、中央ホール左右 の展示室は、短辺方向に仕切られた部屋割りとし、端部の展示室に 繋がっている。つまり教育博物館と同様の順路動線を形成している のである。京都博物館案には尺表記による外形寸法が示されており、 1 フロアの面積は教育博物館の約 3 倍の規模であることが確認でき る。規模が大きいため展示室は S 字に廻れる動線が確保できている。 中央ホールにはオランダ語でWenteltrap（螺旋階段）の表記があり 複数階の構成を想定していたと考えられ、この京都博物館案を整理 したと思われる 2 階建て案も存在している。ヘールツの作成した京 都博物館案の作成時期について、京都国立博物館百年史によると「へ ールツの京都滞在中のものと考えられ、上述の明治八年春から明治 九年夏までのこととなる」 ${ }^{35)}$ とされている。ヘールッの京都滞在期 間は、京都府舎密局司薬場のおかれた明治 8 年 2 月から明治 9 年 8 月までである。36) 教育博物館の計画時期は、明治 8 年 2 月から明治 9 年 3 月までの間であることから教育博物館と京都博物館案の計画 時期はほぼ一致することになる。同時期に非常に似た計画案を作成 していることから、教育博物館との情報交換があった可能性が考え られるが、このことについて考察された論考は見いだせない。

京都博物館は明治 8 年 2 月の博物館論告の発布があり、4 月には 勧業課の所轄下に博物館館組織を設立した。この勧業課は河原町ニ 条下ルの旧長州藩邸跡にあり、博物館事務所もここに置かれていた。 37) 当時京都府大参事であった槙村正直は、勧業政策に積極的であり、 京都博物館の計画にも積極的に取り組んでいたものと考えられる。 博物館事務所が長州藩邸跡に設置され、その敷地選定を槙村正直が
行ったとされている。 ${ }^{38)}$ そして槙村正直自身も南側に隣接した敷地 に居を構えていたことが明らかになっている。 ${ }^{39)}$ 槙村正直は、同じ 長州藩出身の木戸孝允とも交流があったとされており、木戸孝允の 日記によると、槙村正直が木戸孝允と面会や書簡のやりとりを頻繁 にしていることが確認できる。

木戸孝允となると維新の三傑の一人であり、初期の明治政府の実 力者である。木戸孝允は、明治 7 年 1 月 25 日から 5 月 13 日 ${ }^{40)}$ ま で文部卿を勤めている。教育博物館が太政官正院におかれた博覧会 事務局に合併された時にも、単独分離するため明治 7 年 2 月 14 日に 文部卿木戸孝允から太政大臣三条実美に上申書を提出している。つ まり木戸孝允は、一時期教育博物館整備の最高責任者であり、かつ 京都博物館整備の責任者である槙村正直と近い関係にあったことに なる。また教育博物館整備の実行者である田中不二麿にも媣い信頼 を寄せており、明治 4 年の岩倉使節団の洋行時の日記には、「此度同 行中に田中不二麿あり、余の同志なり、且文部省中より随行せり、 不日学校の興隆を只希望する而巳」 ${ }^{41)}$ と記述されている。つまり教 育博物館の田中不二麿と京都博物館の槙村正直は、木戸孝允を通じ て情報伝達が行なわれていたことが推察できる。木戸孝允の日記に よると、教育博物館が計画されたと考えられる明治 8 年 2 月から明 治 9 年 3 月までの間に、木戸孝允は文部卿を既に辞しているにもか かわらず文部大輔の田中不二麿と 14 回会っており交流が続いてい る。そして槙村正直とは 4 回会い、19 回書状のやり取りをしていた ことが確認できる。 ${ }^{42)}$ それだけでなく明治 8 年 7 月 21 日の木戸孝 允の日記に次のような記述がある。

「七字前より畠山義成の招に正二郎と同行寸同客神田孝平槙村忠 直大山覺之助田中不二麿モリ一夫妻なり畠山はモリーと同居なり」 43）教育博物館館長の畠山義成のところに木戸孝允、槙村正直、田中 不二麿、ディビット・マレー夫妻が集まったのである。この時の話の 内容を知る資料は確認できていないが、タイミングとしては、ディ ビット・マレーが渡米する 2 ケ月前である。彼らが教育関係の話題 を中心に、博物館整備に関する情報交換を行った可能性は非常に高 く、施設整備についても話題に上った可能性が高い。この時、ある いはこれに前後して、槙村正直から田中不二麿、畠山義成に京都博 物館案が伝達されたものと考えられる。京都博物館はこのへールツ による京都博物館案を原案として複数の図案が作成されているが、 教育博物館には原案とされる図案の存在が確認できない、また原案 を作成できる人物が見当たらないことからも、教育博物館は京都博 物館案を原案として計画された可能性が高い。

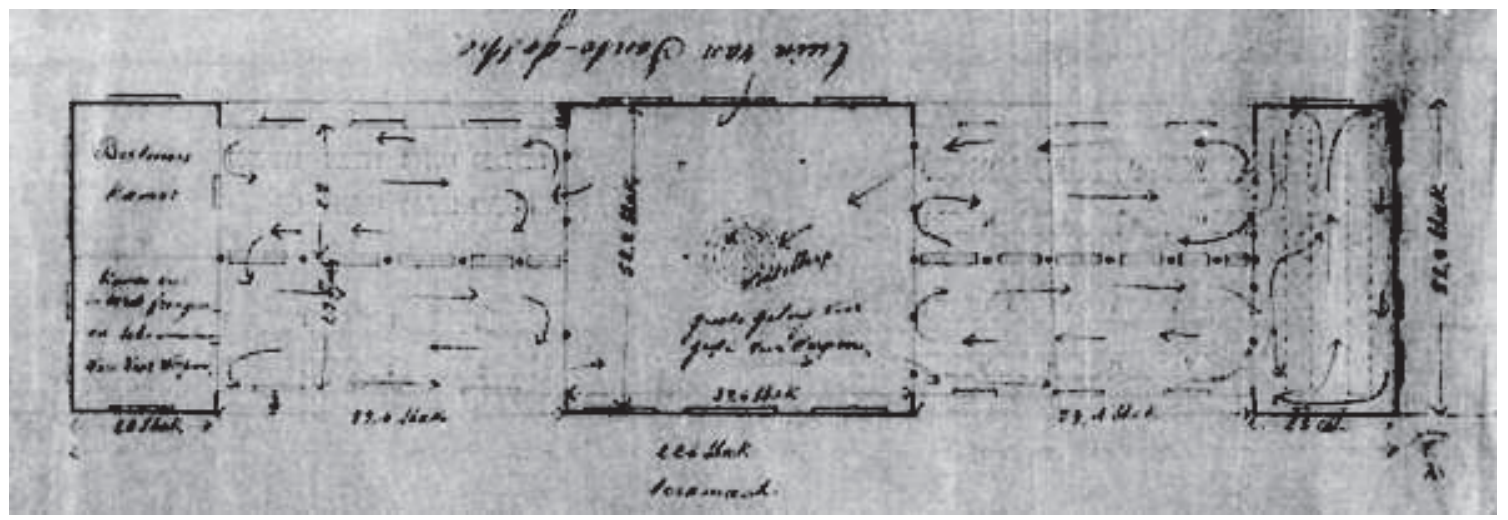

写真 3 京都博物館ヘールツ案 


\section{5. 結}

本稿は教育博物館の平面計画について考察し、施設整備について検 証を行った。

教育博物館は当初より段階的に整備することが想定されており、明 治 10 年の開館当初には、事務室が 2 階に、書籍室が 1 階に配置され、 収蔵庫は無い状態で開館していた。展示室は順路動線で計画されてお り、事務室・書籍室は、正面向かって左側に配置されていたものと推 察できる。明治 12 年 6 月には事務所を増築、 8 月には収蔵庫を増築、 明治 13 年 10 月には書庫及び書籍閲覧室を増築し、さらに明治 12 年、 13 年と 2 度の展示替えを行っている。明治 14 年に発行された「教育 博物館案内」に載せられている平面図は、全館展示室となっており、 当初想定されていた教育博物館の完成形はこれに近いものであった と考えられる。

この教育博物館の計画は、施設整備の経緯から考察すると、単独 分離した明治 8 年 2 月から田中不二麿、畠山義成など責任者が渡米す る前の明治 9 年 3 月までの間に行われたと考えられることができる。 これとほぼ同時期に計画された博物館計画案としてへールツの作成 した京都博物館案が存在し、教育博物館と京都博物館案は非常によく 似た動線計画となっている。つまりこの 2 館は同じ考え方に基づく動 線計画で計画されており、教育博物館は京都博物館案を原案として計 画されたと考えられる。このことについて長州藩出身で元文部卿木戸 孝允を通じて文部大輔田中不二麿と長州藩出身の京都府大参事槙村 正直とは交流があり、この人脈を通して京都博物館案の図案が教育博 物館に伝達されたものと考えられる。

なお明治初期には教育博物館が複数設立されており、設立趣旨や規 則に共通点があることが指摘されている。 ${ }^{44)}$ 今後は施設整備におい ても各館の関連等について順次明らかにしたい。

注

1) 明治 10 年以前に設立された博物館は、明治 4 年文部省の博物館は昌平坂学 問所、明治 6 年太政官正院の博覧会事務局博物館は薩摩藩装束屋敷、明治 8 年奈良博物館は東大寺、明治 9 年金澤博物館は兼六園の成巽閣を利用して 設立されている。

2）教育博物館案内 教育博物館編 1881.6

3）国立科学博物館百年史 国立科学博物館編 $\quad$ p. $103 \quad 1977.10$ 写真で見た国立科学博物館 120 年の歩み 国立科学博物館編 p. 20 1998. 3、椎名仙卓 図解博物館史 雄山閣出版 p. 732000.3 などに掲 載されている。

4）京都国立博物館百年史 京都国立博物館編 $\quad$ p. 42 1997. 10

5）堀越三郎 明治初期の洋風建築 丸善 p.157 1929.12

6）前掲 国立科学博物館百年史 p. 44

7）関秀夫 博物館の誕生 岩波新書 pp. 97-99 2005.6

8）海を越えた日本人名事典 日外アソシエーツ

9）前掲 国立科学博物館百年史 pp. $23-25$

10）前掲 国立科学博物館百年史 pp. 28-29

11）前掲 海を越えた日本人名事典 p. 375

12）吉家定夫 日本国学監ディビット・マレー 玉川大学出版部 pp. $159-163 \quad 1998.1$

13）前掲 国立科学博物館百年史 p. 41

14）アメリカに出張した 5 名については、米国百年期博覧会教育報告 文部省 編 p. 1 1877.1 に記載がある。出張期間については、手島精一先生伝 手島工業教育資金囘 1929 年 p. 33 によると、明治 8 年 4 月 26 日から明治 10 年 1 月 8 日までとなるが、財部香枝 ディヴィット・マレーとスミソニ アン・インスティテューションとの交流 博物館学雑誌 $\quad$ p. 312005.1 によるとディビット・マレーは、明治 9 年 12 月 26 日に帰朝している。マ
レーのみ先に帰ってきているとは考えにくく、出張時期は多少前後するも のと思われる。

15）前掲 国立科学博物館百年史 p. 30

16）前掲 国立科学博物館百年史 pp. 41-42 その他九鬼隆一研究として高橋 眞司 九鬼隆一の研究隆一・波津子・周造 未来社 2008.8 があるが、 九鬼隆一と建築計画を結びつけるような経歴は無い。

17）前掲 国立科学博物館百年史 pp. 64-65

18）文部省年報 文部省 第五第一冊 $\quad$ p. $456 \quad 1877$

19）明治 14 年の教育博物館案内の平面図のスケールを 200 分の 1 と仮定して 面積を算出すると延床面積は $932 \mathrm{~m}^{2}$ となる。実際の延床面積は $724 \mathrm{~m}^{2}$ であ ることから、教育博物館案内の平面図はレイアウトを考慮して、これを約 1.3 倍に拡大されていると想定した。また当時の平面図は尺貫法で作図さ れた可能性が高いが、本稿では規模の概略を把握やすくするためメートル 法で端数をまるめた形で表記した。

20）前揭 国立科学博物館百年史 p. 97

21）前掲 文部省年報 $\quad$ p. 4581877

22）前掲 文部省年報 p. 4591877 書籍欄 存在数の合計である。

23） 7 段高書架 書架間隔 1500 収蔵量 200 冊 $/ \mathrm{m}^{2}$ と想定すると $60 \mathrm{~m}^{2}$ 程度必要 となる。コンパクト建築設計資料集成 丸善 2000.2 p. 200

24）閲覽席 10 席と想定し、(12,326/200+10/0.55) $1.5=119.71 \mathrm{~m}^{2} \quad$ 約 $120 \mathrm{~m}^{2}$ とした。前掲 コンパクト建築設計資料集成 p. 200

25）文部省年報 文部省 第七第 $\quad$ p. 3921879

26）前掲 国立科学博物館百年史 p. 98

27）前掲 文部省年報 文部省 第七第 $\quad$ p. 3931879

28）前掲 文部省年報 文部省 第七第 p. $394 \quad 1879$

29）教育博物館書籍室規則 $\quad$ p. 11879

30）前掲 コンパクト建築設計資料集成 p. 269 これは現代オフィスの設定 だが、今回は一つの目安として参照した。

31）前掲 文部省年報 文部省 第八第 $\quad$ p. $501 \quad 1880$

32）日本その日その日 2 (全 3 卷) $\quad$ E. S. モース (石川欣一訳) 平凡社 pp. 3-4 1970 に教育博物館の記載がある。「日本その日その日」の中に教育博物 館の記載があること自体は、椎名仙卓「モースの発掘」恒和出版 1988 の なかで既に明らかとなっている。

33）魚類の展示が充実していたことについては、明治 10 年段階でモース自身 から「合衆国周辺の海洋生物の標本 1 セット」、ベアードより「魚類の複 製セット」、そのほかスミソニアン・インスティテューションより魚類の アルコール漬けのセットを購入していたことが明らかにされている。財部 香枝「ディビット・マレーとスミソニアン・インスティテューションと の交流」博物館学雑誌 全日本博物館学会 pp. 31-32 2005.1

34）洋食レストランでの 1 席当りの床面積を $1.5 \mathrm{~m}^{2} /$ 人と想定すると、100 人で $150 \mathrm{~m}^{2}$ 必要となる。前揭 コンパクト建築設計資料集成 p. 62

35）前掲 京都国立博物館百年史 p. 42

36）根本曾代子「ヘールツ先生没後 100 周年の回想」薬史学雑誌 第 17 巻第 2 号 p. $83 \quad 1982$

37）前掲 京都国立博物館百年史 p. 32

38）川村鸴昭 鳥地黙雷の教育思想研究 - 明治維新と異文化理解 法藏館 p. 1932004

39）明田鉄男 維新京都を救った豪腕知事 小学館 p. 722004

40）大江志乃夫 木戸孝允 中公新書 p. 193 1986.3

41）木戸孝允日記二 日本史跡協会 p. $127 \quad 1985$

42）前掲 木戸孝允日記三 pp. 147-310 木戸孝允の日記は、その日に合った 人物、書簡のやり取りについて氏名役職まで明記されている。

43）前掲 木戸孝允日記三 pp. 212-213 正二郎は木戸正二郎、神田孝平は兵 庫県大参事、大山覺之助は格之助のことで鹿児島県大参事、モリ一夫妻は ディビット・マレー夫妻のことである。㯖村忠直は正直の誤記である。

44）椎名仙卓「博物館発達史」雄山閣 p. 521988 佐藤修啓「明治期における教育博物館の発展と変容」名古屋大学博士論文 PP. 59-60 2003

写真 1 : 教育博物館案内 教育博物館編 1881.6 口絵

写真 2 : 教育博物館案内 教育博物館編 1881.6 口絵

写真 3 : 京都国立博物館百年史 京都国立博物館編 $\quad$ p.42 1997.10 